\title{
Edge-Interior Disparities in Tree Species and Structural Composition of the Kilengwe Forest in Morogoro Region, Tanzania
}

\author{
David Sylvester Kacholi \\ Department of Biological Sciences, Dar es Salaam University College of Education (DUCE), P.O. Box 2329, Dar es Salaam, Tanzania
}

Correspondence should be addressed to David Sylvester Kacholi; kacholi78@yahoo.com

Received 17 December 2013; Accepted 12 March 2014; Published 26 March 2014

Academic Editors: H. Ford and P. M. Vergara

Copyright (C) 2014 David Sylvester Kacholi. This is an open access article distributed under the Creative Commons Attribution License, which permits unrestricted use, distribution, and reproduction in any medium, provided the original work is properly cited.

\begin{abstract}
A survey to determine the variation in species and structural composition of trees along the edge-interior gradient was done in the Kilengwe forest in Morogoro region, Tanzania. The forest was categorized into three habitats, namely, edge (0-100 m), intermediate $(100-200 \mathrm{~m})$, and interior $(>200 \mathrm{~m})$ depending on the distance from the forest margin. A total of six plots of 0.04 ha each were randomly placed in each of the habitats whereby all trees with $\mathrm{DBH} \geq 10 \mathrm{~cm}$ were inventoried. A total of 67 species representing 26 families were recorded. Fabaceae was the most speciose and abundant family. Brachystegia spiciformis was the most abundant species. Of the recorded species, $10.45 \%$ were common in the three habitats while $8.95 \%, 13.43 \%$, and $26.86 \%$ occurred exclusively to the edge, intermediate, and interior habitats, respectively. The forest interior was significantly rich in terms of species richness, diversity, density, and basal area than the edge and intermediate habitats. The edge had significantly higher number of stumps/ha. In summary, the results suggest that edge/intermediate and interior are contrasting habitats in terms of tree species richness, diversity, and structural composition. Moreover, the forest edge and intermediate habitats were found to be characterized by high anthropogenic activities compared to the forest interior habitat.
\end{abstract}

\section{Introduction}

Forest fragmentation and deforestation are among the critical environmental problems with possible implications on a global scale $[1,2]$ as human activities convert continuous forests into number of patches [3]. The tropical forests that encompass $6 \%$ of the world's land area and harbor at least $50 \%$ of the world's biodiversity are deforested and fragmented at an alarming rate $[4,5]$. For instance, the global annual losses of $5.2 \times 106$ ha/year and $8.3 \times 106$ ha/year due to fragmentation and deforestation in the tropical forest area were recorded between 1990-2000 and 2000-2010, respectively [6]. In Tanzania, the annual loss of forest cover increased by $37 \%$ from the period of $1990-1995$ (322,000 ha/year) to $2000-$ 2010 (403,000 ha/year), which was mainly due to increased demand as the population grows $[6,7]$. The forest fragmentation process disrupts structure and spatial continuity as it reduces original area, increases edge formation, and isolates remaining forest patches $[3,8]$. The formation of edges is recognized to be fundamental of ecological change as it involves alteration of microclimatic conditions, enhances invasion by exotic species, and increases the human pressure $[9,10]$. Due to this, several organisms, for instance, mammals, amphibians, birds, and tree communities, have been reported to suffer significant changes in their local abundance and distribution in the forest fragments [11-14].

Various studies done in the tropical forests have reported negative impacts of forest fragmentation, mainly associated with the edge effects. These impacts include (1) reduction in recruitment rates of trees due to habitat desiccation and seedling damage by litter and tree falling near forest edges [11], (2) increasing sapling mortality rate by competition with lianas, vines, and ruderal species [15], and (3) increased mature tree mortality due to increased rates of uprooting and breakage near forest edges $[2,15,16]$, which results in the decrease in canopy height $[17,18]$. Due to the above explained 
effects and other edge-related processes, it is reasonable to expect that tree species in the forest edges will differ markedly from the forest interior in terms of species richness, diversity, and structure as well as ecological and taxonomical composition $[12,19,20]$.

The Eastern Arc and Coastal forests (Kilengwe inclusive) of Tanzania are known to be centers of endemism, but the forests are facing danger of losing some of these due to increased anthropogenic activities as a result of population growth and fragmentation [21-23]. Thus, determining how tree species diversity and abundance vary within forests is a vital step in plant ecology and biodiversity conservation [9]. In Tanzania, no known study has examined the edge-interior differences in the tree species and structural composition in any forest. Thus, due to the existence of this knowledge gap, this study intends to (1) provide an understanding of the existing knowledge discrepancy by comparing the species richness, diversity, abundance, and basal area of tree communities along edge-interior gradient in the Kilengwe forest reserve and (2) quantify and compare impact of anthropogenic disturbances using number of stamps/ha observed in each established habitat. The findings from this study will contribute to the management of the forest reserve and other similar tropical forests in Tanzania and elsewhere.

\section{Materials and Methods}

2.1. Description of the Study Site. The Kilengwe Forest Reserve is located at latitude $7^{\prime} 29^{\circ}$ South and longitude $37^{\prime}$ $32^{\circ}$ East at an elevation of 182 to $228 \mathrm{~m}$ above mean sea level covering an area of 995 ha. The forest is in Kisaki Ward, Bwakira Chini Division in the Morogoro Rural District. The forest is surrounded by two villages, namely, Kilengwe and Zongomero, and is owned and managed by the local government. A number of seasonal streams that provide water to the local community for domestic purpose originate from this forest reserve. The climate of the region is oceanic due to nearness (about $200 \mathrm{~km}$ ) to the Indian Ocean and the rainfall regime is bimodal. The long rains last from March to May, peaking in April while the short rains last from October to December. The mean annual rainfall and temperature in the Morogoro region are about $740 \mathrm{~mm}$ and $25.1^{\circ} \mathrm{C}$, respectively. Agriculture is the most important socioeconomic activity done by locals living in the two adjacent villages. Other land use practices done by locals include livestock keeping, especially poultry, goats, and cows. Bee keeping and carpentry are done at small scale. Illegal logging activities were observed in the forest, especially close to the edges.

2.2. Data Collection. To characterize tree species and structural composition between edge $(0-100 \mathrm{~m})$, intermediate $(100-200 \mathrm{~m})$, and interior $(>200 \mathrm{~m})$ of the forest, six plots of $20 \mathrm{~m} \times 20 \mathrm{~m}$ were randomly placed in each of the three established forest habitats. This design was due to the fact that the edge effects can penetrate to $100 \mathrm{~m}$ to the forest interior from the margin [2]. In each plot, all trees with diameter at breast height $(\mathrm{DBH}) \geq 10 \mathrm{~cm}$ measured at $1.3 \mathrm{~m}$ above the ground were counted and identified and stem diameters were recorded from each plot in the habitats. Trees with multiple stems at $1.3 \mathrm{~m}$ height were treated as the single individual whereby the diameters of all stems were taken and averaged. If a tree had buttress or an abnormality at $1.3 \mathrm{~m}$ height, the diameter was measured just above the buttress where the stem assumes near cylindrical shape. The identification was done with the help of an expert from the forest department of the Morogoro region. Also, in each plot, tree stumps were counted and recorded. Each plot among the established habitats was considered as an independent sample.

2.3. Data Analysis. Species diversity was calculated using the Shannon-Wiener diversity index $\left(\mathrm{H}^{\prime}\right)$ and Margalef index (D) while the equitability was determined by Pielou's evenness using the Species Richness and Diversity IV (SDR IV) software [24]. Species richness was expressed by the number of observed species in the forest while the first order Jackknife species richness estimator was used to estimate potential species richness in the three studied habitats [25]. The species accumulation curves were constructed for comparing the increase of the number of species with increasing sample area within the habitats. The forest structure was explained in terms of density (stems/ha) and basal area $\left(\mathrm{m}^{2} / \mathrm{ha}\right)$. A multivariate agglomerative clustering technique using the Ward's group linkage based on the Bray-Curtis distance measure was performed using the Community Analysis Package 4 (CAP IV) software [24] to analyze species compositional similarities between the studied habitats. The significant differences in structural composition and stumps/ha between the three habitats were tested using the One Way Analysis of Variance (ANOVA) followed by the post hoc Tukey's Highly Significance Difference (Tukey's HSD) test at the 5\% significance level using the QED statistical software [24]. Before undertaking ANOVA, all the data were tested for normality using the Shapiro-Wilk tests.

\section{Results}

3.1. Overall Floristic Composition and Abundance. A total of 199 stems belonging to 67 tree species and 26 families were recorded from an area of 0.72 ha. Family Fabaceae was the most dominant family with 21 species in the studied area of the forest, followed by Moraceae ( 5 species), and Sterculiaceae (4 species). The most abundant species were Brachystegia spiciformis with a relative abundance of $4.02 \%$, followed by Julbernardia globiflora, Burke Africana, and Synsepalum cerasiferum with a relative abundance of $3.52 \%$ each. $B$. spiciformis and J. globiflora were the most frequent species in the studied area with a relative frequency of $3.73 \%$ each. Of the total observed species, $10.45 \%$ (7 species: Acacia nigrescens, Albizia glaberrima, B. spiciformis, Cussonia spicata, S. cerasiferum, Vitex doniana, andStereospermum kunthianum) were common in all the three studied forest habitats while $8.95 \%$ (6 species), $13.43 \%$ (9 species), and $26.86 \%$ (18 species) occurred exclusively to the edge, intermediate, and interior habitats, respectively (see Table 1). 
TABLE 1: The tree species distribution and abundance in the edge, intermediate, and interior of the forest.

\begin{tabular}{|c|c|c|c|c|c|c|}
\hline Scientific names & Family & Edge & Intermediate & Interior & Total & Relative abundance \\
\hline Brachystegia spiciformis Benth. & Fabaceae & 2 & 3 & 3 & 8 & 4.02 \\
\hline Burkea Africana Hook. f. & Fabaceae & 1 & - & 6 & 7 & 3.52 \\
\hline Jubernadia globiflora (Benth.) Troupin & Fabaceae & - & 2 & 5 & 7 & 3.52 \\
\hline Synsepalum cerasiferum (Welw.) T.D.Penn. & Sapotaceae & 2 & 1 & 4 & 7 & 3.52 \\
\hline Bauhinia petersiana Bolle & Fabaceae & 1 & - & 5 & 6 & 3.02 \\
\hline Dombeya natalensis Sond. & Sterculiaceae & - & - & 6 & 6 & 3.02 \\
\hline Ophrypetalum odoratum Diels. & Annonaceae & - & 2 & 4 & 6 & 3.02 \\
\hline Acacia nigrescens Oliv. & Fabaceae & 1 & 2 & 2 & 5 & 2.51 \\
\hline Diospyros squarrosa Klotzsch. & Ebenaceae & - & 2 & 3 & 5 & 2.51 \\
\hline Ehretia amoena Klotzsch. & Boraginaceae & 1 & 4 & - & 5 & 2.51 \\
\hline Stereospermum kunthianum Cham. & Bignoniaceae & 2 & 2 & 1 & 5 & 2.51 \\
\hline Vitex doniana Sweet & Verbenaceae & 1 & 2 & 2 & 5 & 2.51 \\
\hline Albizia glaberrima (Schum. and Thonn.) Benth. & Fabaceae & 2 & 2 & 1 & 5 & 2.50 \\
\hline Dalbergia boehmii Taub. & Fabaceae & - & 1 & 4 & 5 & 2.50 \\
\hline Albizia versicolor Welw. ex Oliver & Fabaceae & - & - & 4 & 4 & 2.01 \\
\hline Cynometra uluguruensis Harms. & Fabaceae & 1 & - & 3 & 4 & 2.01 \\
\hline Deinbollia borbonica Scheff. & Sapindaceae & 3 & - & 1 & 4 & 2.01 \\
\hline Markhamia obtusifolia (Baker) Sprague. & Bignoniaceae & - & 1 & 3 & 4 & 2.01 \\
\hline Myrianthus holstii Engl. & Moraceae & - & - & 4 & 4 & 2.01 \\
\hline Oncoba spinosa Forssk. & Salicaceae & - & 4 & - & 4 & 2.01 \\
\hline Sclerocarya birrea (A. Rich.) Hochst & Anacardiaceae & - & - & 4 & 4 & 2.01 \\
\hline Strychnos spinosa Lam. & Loganiaceae & - & 4 & - & 4 & 2.01 \\
\hline Terminalia sambesiaca Engl. and Diels. & Combretaceae & - & - & 4 & 4 & 2.01 \\
\hline Trema orientalis (L.) Blume & Ulmaceae & 2 & - & 2 & 4 & 2.01 \\
\hline Combretum molle R.Br. ex G.Don. & Combretaceae & 3 & - & - & 3 & 1.51 \\
\hline Commiphora africana (A. Rich.) Endl. & Burseraceae & - & 1 & 2 & 3 & 1.51 \\
\hline Cussonia spicata Thunb. & Araliaceae & 1 & 1 & 1 & 3 & 1.51 \\
\hline Dalbergia melanoxylon Guill. and Perr. & Fabaceae & - & 2 & 1 & 3 & 1.51 \\
\hline Dombeya rotundifolia (Hochst.) Planch. & Sterculiaceae & 1 & 2 & - & 3 & 1.51 \\
\hline Khaya anthotheca (Welw.) C. DC. & Meliaceae & 1 & 2 & - & 3 & 1.51 \\
\hline Sterculia quinqueloba (Garcke) K. Schum. & Sterculiaceae & 1 & - & 2 & 3 & 1.51 \\
\hline Acacia polyacantha Wild. & Fabaceae & - & 1 & 2 & 3 & 1.50 \\
\hline Acacia seyal Del. & Fabaceae & - & 1 & 2 & 3 & 1.50 \\
\hline Albizia petersiana (Bolle) Oliv. & Fabaceae & - & - & 3 & 3 & 1.50 \\
\hline Acacia caffra Thunb. Wild. & Fabaceae & 1 & - & 1 & 2 & 1.01 \\
\hline Allanblackia uluguruensis Engl. & Clusiaceae & 1 & 1 & - & 2 & 1.01 \\
\hline Anthocleista grandiflora $\mathrm{L}$. & Loganiaceae & 1 & - & 1 & 2 & 1.01 \\
\hline Antiaris toxicaria Lesch. & Moraceae & - & - & 2 & 2 & 1.01 \\
\hline Brachystegia temarindoides Benth. & Fabaceae & 1 & - & 1 & 2 & 1.01 \\
\hline Breonadia salicina (Vahl) Happer and J.R.I. Wood & Rubiaceae & 1 & 1 & - & 2 & 1.01 \\
\hline Bridelia micrantha (Hochst.) Baill. & Euphorbiaceae & - & 2 & - & 2 & 1.01 \\
\hline Cassipourea mallosana Alston & Rhizophoraceae & 2 & - & - & 2 & 1.01 \\
\hline Englerophytum natalense (Sond.) T.D. Penn. & Sapotaceae & - & - & 2 & 2 & 1.01 \\
\hline Ficus exasperata Vahl. & Moraceae & - & 1 & 1 & 2 & 1.01 \\
\hline Ficus lutea Vahl. & Moraceae & - & 2 & - & 2 & 1.01 \\
\hline Grewia similis K. Schum. & Tiliaceae & 1 & - & 1 & 2 & 1.01 \\
\hline Margaritaria discoidea (Baill.) G.L. Webster & Euphorbiaceae & - & 1 & 1 & 2 & 1.01 \\
\hline Parkia filicoidea Welw. & Fabaceae & 1 & - & 1 & 2 & 1.01 \\
\hline Annona senegalensis Pers. & Annonaceae & - & 1 & - & 1 & 0.50 \\
\hline Cassia abbreviate Oliv. & Fabaceae & - & - & 1 & 1 & 0.50 \\
\hline Combretum adenogonium Steud. ex Rich. & Combretaceae & - & 1 & - & 1 & 0.50 \\
\hline
\end{tabular}


TABle 1: Continued.

\begin{tabular}{|c|c|c|c|c|c|c|}
\hline Scientific names & Family & Edge & Intermediate & Interior & Total & Relative abundance \\
\hline Commiphora eminii Engl. & Burseraceae & - & - & 1 & 1 & 0.50 \\
\hline Cussonia zimmermannii Harms. & Araliaceae & - & - & 1 & 1 & 0.50 \\
\hline Diplorhynchus condylocarpon (Muell. Arg.) Pichon & Apocynaceae & - & - & 1 & 1 & 0.50 \\
\hline Erythrophleum suaveolens (Guill and Perr) Brennan & Fabaceae & - & 1 & - & 1 & 0.50 \\
\hline Harrisonia abyssinica Oliv. & Simaroubaceae & - & - & 1 & 1 & 0.50 \\
\hline Harungana madagascariensis Lam. ex Poiret & Clusiaceae & - & - & 1 & 1 & 0.50 \\
\hline Lonchocarpus bussei Harms. & Fabaceae & 1 & - & - & 1 & 0.50 \\
\hline Markhamia zanzibarica Bojer ex DC. & Bignoniaceae & 1 & - & - & 1 & 0.50 \\
\hline Milicia excelsa (Welw.) C.C. Berg & Moraceae & - & 1 & - & 1 & 0.50 \\
\hline Oxyanthus goetzei K. Schum & Rubiaceae & - & - & 1 & 1 & 0.50 \\
\hline Pouteria altissima Baehni & Sapotaceae & - & - & 1 & 1 & 0.50 \\
\hline Pseudolachnostylis maprouneifolia Pax & Phyllanthaceae & - & - & 1 & 1 & 0.50 \\
\hline Pterocarpus tinctorius Welw. & Fabaceae & - & - & 1 & 1 & 0.50 \\
\hline Scorodophloeus fischeri (Taub.) J. Leon & Fabaceae & 1 & - & - & 1 & 0.50 \\
\hline Sterculia appendiculata K. Schum. & Sterculiaceae & 1 & - & - & 1 & 0.50 \\
\hline Tabernaemontana pachysiphon Stapf & Apocynaceae & - & 1 & - & 1 & 0.50 \\
\hline Total & & 39 & 55 & 105 & 199 & 100 \\
\hline
\end{tabular}

3.2. Species Diversity, Similarity, and Species Accumulation Curves. The species richness, Shannon-Wiener diversity index $\left(\mathrm{H}^{\prime}\right)$, Margalef index (D), Pielou's Evenness (E), and the first order Jackknife estimates of the studied habitats are shown in Table 2. The forest interior habitat was revealed to be the most diverse community with significantly higher species richness (47 species), Shannon-Wiener index (3.65), and Margalef index (9.86) compared to edge and intermediate habitats, which did not differ appreciably. Though evenness did not differ significantly between habitats, the edge community had relatively higher evenness than other habitats. Figure 1 shows the similarity between the three studied habitats. The distance correlation (Ward linkage using the Bray-Curtis measure) between the edge and intermediate is minimal, and this explains that edge and intermediate had a high similarity index (0.32). The forest interior habitat was less similar to edge and intermediate habitats (see Figure 1). The species accumulation curves (Figure 2) revealed an increasing trend as the number of sample areas increased in each studied habitat. The first order Jackknife species richness estimator projected higher species richness in each studied habitat than the observed ones (Table 2). Moreover, the rate of species increase per unit area (i.e., regression slope) was significantly higher in the interior habitat compared to edge and intermediate habitats, which did not differ substantially (Table 3).

3.3. Structural Composition. The densities of stems between the studied forest habitats varied significantly $(F(2,15)=$ $15.18, P=0.002$ ) ranging from 163 stems/ha (at the edge) to 442 stems/ha (at the interior) with an overall average of 278 stems/ha when all habitats are pooled together (Figure 3 ). Post hoc Tukey's HSD test $(P<0.05)$ confirmed the interior to have a significantly higher density than edge and intermediate, which did not differ appreciably $(P>0.05)$ in their tree densities. The basal areas differed significantly between the studied habitats $(F(2,15)=5.98, P=0.01)$ ranging from $3.7 \mathrm{~m}^{2} / \mathrm{ha}$ (at the edge) to $11.1 \mathrm{~m}^{2} / \mathrm{ha}$ (at the interior) (Figure 4). Post hoc Tukey's HSD test $(P<0.05)$ revealed the interior of the forest to have a significantly higher basal area compared to the edge and intermediate, which also did not differ considerably $(P>0.05)$ in their basal areas. The species with the highest basal areas were Dalbergia melanoxylon and J. globiflora with a relative basal area of $8.10 \%$ and $6.00 \%$, respectively. Moreover, number of stumps/ha among the habitats varied extensively $(F(2,15)=$ $5.19, P=0.02$ ) from 2 to 14 stumps/ha (Figure 5). Post hoc Tukey's HSD test $(P<0.05)$ revealed the forest edge $(2$ stumps/ha) to have a significantly lower number of stumps/ha than intermediate (8 stumps/ha) and interior (14 stumps/ha), which also differed significantly in their number of stumps/ha $(P<0.05)$.

\section{Discussion}

4.1. Overall Floristic Composition of the Forest. Tropical forests are recognized to harbor more than half of the global species richness, and they are often subjected to increasing anthropogenic pressure, which poses a great threat to existing biodiversity [26]. The Eastern Arc and Coastal forests of Tanzania (Kilengwe inclusive) are known to be rich in species diversity as they are located within the region of high rainfall and habitat heterogeneity [27]. This study has observed Fabaceae to be the most dominant family (with 21 species), which implies that the Fabaceae could be the most dominant tree family in the region. This finding is in line with the results of other authors [22, 28-30] who reported the same family to be the most dominant tree family in the Coastal and Eastern Arc forests of Tanzania. The family Fabaceae was reported to dominate by $25 \%-50 \%[28,31,32]$ and by $33 \%$ [22] in their studies. The present study revealed the Fabaceae to dominate by $31 \%$. Moreover, like many other studies done 
TABLE 2: Species richness, diversity indices, and evenness values of the three studied habitats.

\begin{tabular}{lccccc}
\hline Habitats & Observed species richness $( \pm$ SE) & Jackknife 1 $( \pm$ SE) & Shannon-Wiener $\left(\mathrm{H}^{\prime}\right)$ & Margalef index $(\mathrm{D})$ & Pielou's evenness $(\mathrm{E})$ \\
\hline Edge & $29 \pm 4^{\mathrm{a}}$ & $51 \pm 4^{\mathrm{a}}$ & $3.28 \pm 0.19^{\mathrm{a}}$ & $7.64 \pm 1.03^{\mathrm{a}}$ & $0.97 \pm 0.06$ \\
Intermediate & $32 \pm 2^{\mathrm{a}}$ & $47 \pm 2^{\mathrm{a}}$ & $3.34 \pm 0.05^{\mathrm{a}}$ & $7.74 \pm 0.40^{\mathrm{a}}$ & $0.96 \pm 0.02$ \\
Interior & $47 \pm 5^{\mathrm{b}}$ & $68 \pm 5^{\mathrm{b}}$ & $3.65 \pm 0.11^{\mathrm{b}}$ & $9.86 \pm 0.94^{\mathrm{b}}$ & $0.95 \pm 0.03$ \\
\hline
\end{tabular}

Note: values with different letters indicate significant differences between habitats (Tukey's HSD test, $P=0.05$ ).

elsewhere [33-37] this study confirms that the Fabaceae is the speciose family in most of the lowland forests of Africa. Other recorded families in this study have similarly been reported by various authors $[29,30,32]$ in their studies in the Eastern Arc and Coastal forests of Tanzania.

4.2. Species and Structural Composition along the EdgeInterior Gradient. The study has registered a clear pattern of changes in the tree community whereby the tree species diversity, richness, density, and basal area increased towards the forest interior (Table 2, Figures 2 and 4). In all cases, the forest interior habitat had significantly higher values than the edge and intermediate habitats, which did not differ appreciably. The results signify that edge effects can penetrate to a distance of $200 \mathrm{~m}$ from the forest margin. Also, these findings suggest that the forest interior and the edge/intermediate are contrasting habitats. A forest community is said to be speciose if it has a Shannon-Wiener diversity index value $\geq 3.5$ [38]. This confirms the observation of this study, which revealed significantly higher Shannon-Wiener diversity index value of 3.65 compared to edge (3.28) and intermediate (3.34) habitats. The presence of less species diversity, richness, density, and basal area at the edges and intermediate can be linked to the fact that these two habitats are easily accessible by local people while fetching for their basic needs like firewood, charcoal, building poles, and traditional medicines [22]. The observed illegal timber harvest contributes to the observed low values, especially on tree density and basal area on the edge/intermediate habitats as it is easier for the timber thieves to cut and carry logs to the truck during the night $[22,39]$. The grazing and cattle trampling can also be the causal factor for the observed low values at edges as livestock were observed to reach the forest edges in the studied forest. The Luguru people prefer to use fire to prepare their farms before starting a new agricultural season and for hunting bush animals like Hyrax pimbi, Sus scrofa, and Thryonomys spp., which are used for nutritional purposes. The penetration of fire to forest edges could also account for the observed low species diversity and density values as it kills the fire-sensitive species and affects their regeneration $[10,22]$. The periodic fires reduce canopy cover and drastically change vegetation structure and composition [15, 39]. Another observed important factor was the action of sporadic winds that cause great damage to tree communities and high mortality of canopy trees at the edges, which subsequently affect the composition and abundance. Moreover, the present findings are comparable to other works done in Brazil and other countries, in which the forest interior was found to be rich in species diversity and the penetration of edge effects was reported to vary from $15 \mathrm{~m}$ to $200 \mathrm{~m}[12,40-43]$. Distinct abiotic conditions [18, 40-42, 44],

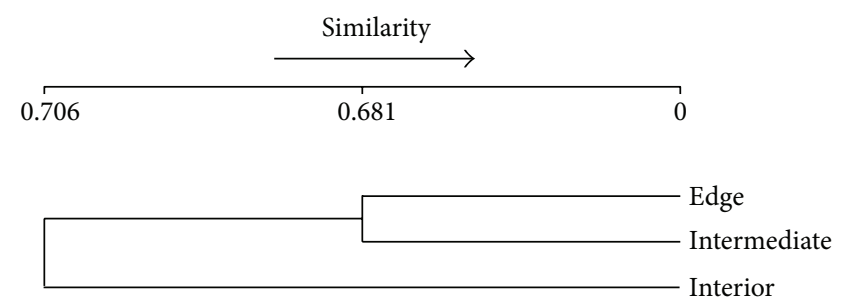

FIGURE 1: Similarity in species composition between the three studied habitats.

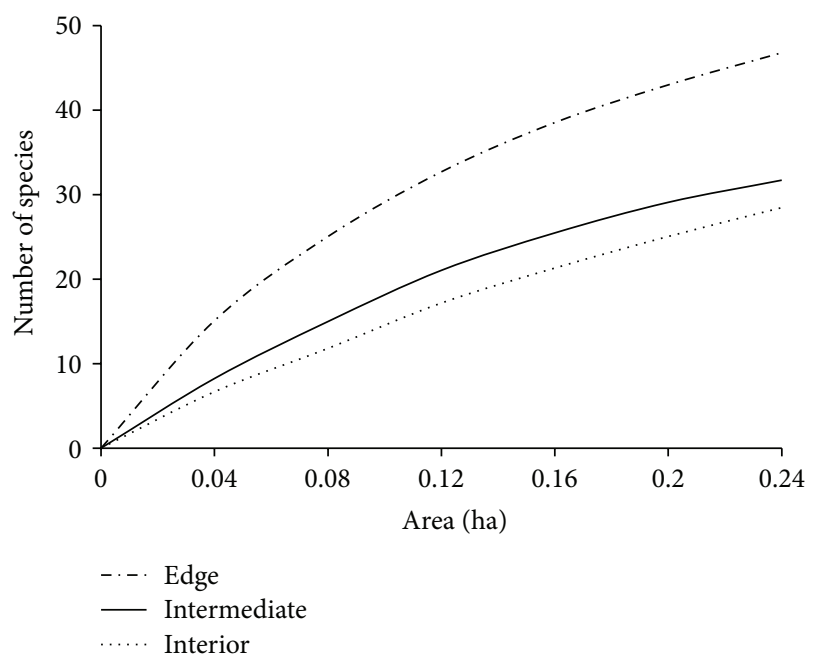

FIGURE 2: Species-area curves based on the cumulative sample area in the studied habitats.

vegetation structure [40], tree mortality rate [2], and high predation, loss of pollinators, and seed dispersers, at edges [11], were reported to be the common cause of differences in species composition between forest edge and interior in various studies done elsewhere.

The presence of significantly less tree density at the edges/intermediate habitats may also be the result of the interplay of factors of two kinds: firstly, those that reduce the possibility of seedling establishment as seedling is the first size class to be affected by edge effects due to its sensitivity to environmental changes and biotic interactions $[9,10]$, and secondly, those factors that increase seedling, sapling, and adult tree mortality rate [11]. Some processes related to edge effects that could have contributed to low tree density on the edge/intermediate habitats include; reduction in seedling recruitment at edges due to uprooting and breakage due to wind turbulence $[2,45]$, seedling damage caused by an increasing litter fall near forest edges [11], sapling mortality 


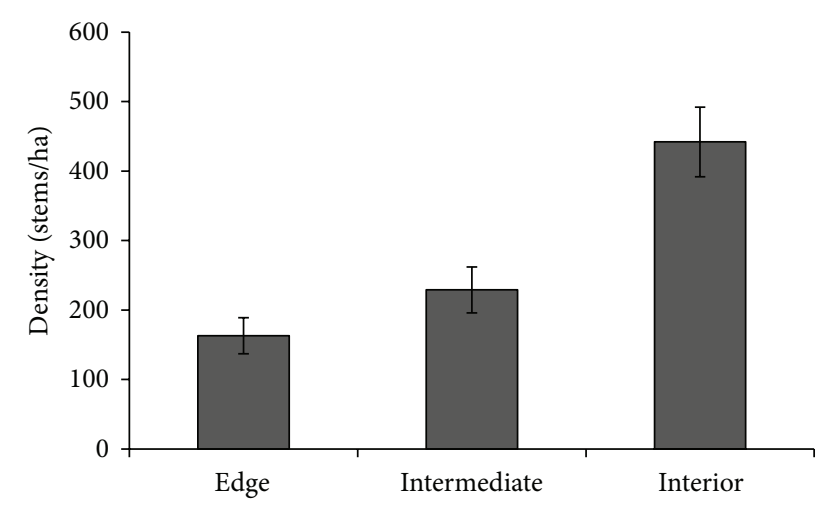

FIGURE 3: Mean tree density ( \pm standard error) in the three studied forest habitats.

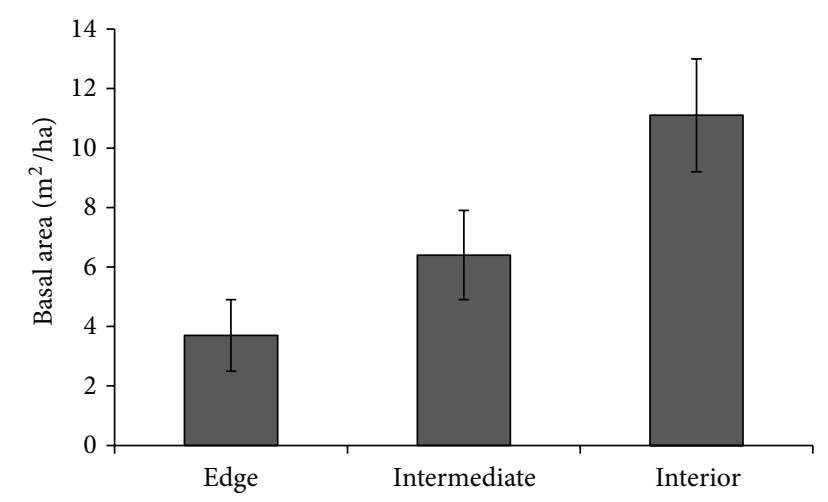

Figure 4: Mean basal area ( \pm standard error) in the three studied forest habitats.

TABLE 3: Relationship between species richness and forest area.

\begin{tabular}{lcc}
\hline Location & $r^{2}$-value & Regression equation \\
\hline Edge & 0.99 & Species richness $=14.72 \ln$ area -2.15 \\
Intermediate & 0.98 & Species richness $=16.77 \ln$ area -1.78 \\
Interior & 0.97 & Species richness $=24.32 \ln$ area -0.88 \\
\hline
\end{tabular}

by competition with lianas, vines, and invasive species $[2,46]$, and easy accessibility to edges by locals and their livestock [47]. Also, the low basal area at the edge and intermediate habitats could be the result of continuing anthropogenic activities especially illegal logging done by unfaithful locals. Various authors have indicated that the presence of harsh microenvironmental conditions such as air and soil temperatures, high light transmittance, lower relative humidity $[17,23,48]$, increased wind forces [2], lower availability of soil carbon, total nitrogen and phosphorus [49], and lower soil and litter moisture [17, 49] near edges contributes to drastic changes in the abundance and distribution of trees in the forest.

4.3. Species Accumulation Curves. The species-area curves displayed an escalating trend, which suggest that increasing the sampling effort could have increased the species richness observed in each habitat. This is due to the fact that the larger

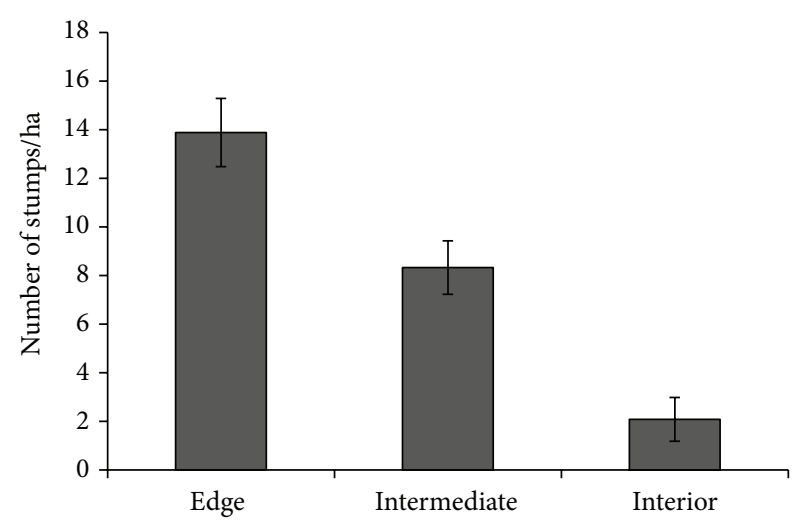

FIGURE 5: Mean stumps/ha ( \pm standard error) in the three studied forest habitats.

the forest area sampled is the more environmentally heterogeneous the sampling area becomes and hence the higher the possibility of having many species is. The observed trend in both curves concurs with the first order Jackknife species richness estimator, which provides higher species richness estimates than the observed in each studied habitat. This observation basically informs us that the sample size used was not enough to capture all the species in the forest habitats, which implies that more plots will be required for future inventories in the habitats. Furthermore, the regression slopes have registered an increasing trend from the edge to the forest interior habitat (Table 3). This observation provides a clear indication that the interior habitat is rich and has a high recruitment rate per unit area than edge and intermediate habitats, which did not differ markedly. The observation can possibly be linked with ongoing anthropogenic disturbances observed at the edge and intermediate habitats (Figure 5) whereby the number of stumps/ha was significantly higher in these two habitats compared to the forest interior habitat.

\section{Conclusion}

In summary, the findings indicate that the edge/intermediate habitats are different from the forest interior in terms of tree species richness, diversity, and structural composition. The forest interior possesses higher species richness, diversity, tree density, and basal area while forest edges and intermediate habitats had impoverished assemblage of tree species, diversity, and density. Also, the edge and intermediate were characterized by high anthropogenic activities by having more stumps/ha than forest interior habitat. If the Kilengwe forest will continue being fragmented, there will be an increase of edge related habitats, which will cause structural and floristic composition changes due to increased edge effects and the forest will face a great threat of losing its original biota especially the rare species. The study recommends longterm research to study microenvironmental factors such as light availability, air and soil temperature, humidity, and nutrients along the edge-interior gradient in the forest in order to determine their influence on tree species richness, composition, and structure. 


\section{Conflict of Interests}

The author declares that there is no conflict of interests regarding the publication of this paper.

\section{Acknowledgments}

The author is specially thankful to the Dar es Salaam University College of Education (DUCE) and the Deutscher Akademischer Austausch Dienst (DAAD) for funding this study. The thanks are also extended to the Morogoro Forest Department for permission to access the forest and providing technical and transport logistics to and from the study sites.

\section{References}

[1] B. L. Turner II and W. B. Meyer, "Land use and land cover in global environmental change: considerations for study," International Social Science Journal, vol. 43, no. 130, pp. 669679, 1991.

[2] W. F. Laurance, L. V. Ferreira, J. M. Rankin-de Merona, and S. G. Laurance, "Rain forest fragmentation and the dynamics of Amazonian tree communities," Ecology, vol. 79, no. 6, pp. 20322040, 1998.

[3] L. Fahrig, "Effects of Habitat Fragmentation on Biodiversity," Annual Review of Ecology, Evolution, and Systematics, vol. 34, pp. 487-515, 2003.

[4] P. Ehrlich and A. Ehrlich, Extinction, Oxford University Press, Oxford, UK, 1981.

[5] S. L. Pimm, G.J. Russell, J. L. Gittleman, and T. M. Brooks, "The future of biodiversity," Advances in Complex Systems, vol. 1, p. 203, 1998.

[6] Food and Agriculture Organization of the United Nation (FAO), "Global forest resources assessment 2010," FAO paper 163, Rome, Italy, 2010.

[7] W. D. Newmark, Conserving Biodiversity in East African Forests. A Study of the Eastern Arc Mountains, Springer, New York, NY, USA, 2002.

[8] S. Walker, G. M. Rogers, W. G. Lee et al., "Consequences to threatened plants and insects of fragmentation of Southland floodplain forests," Science for Conservation, vol. 265, p. 86, 2006.

[9] C. Murcia, "Edge effects in fragmented forests: implications for conservation," Trends in Ecology and Evolution, vol. 10, no. 2, pp. 58-62, 1995.

[10] D. A. Saunders, R. J. Hobbs, and C. R. Margules, "Biological consequences of ecosystem fragmentation: a review," Conservation Biology, vol. 5, no. 1, pp. 18-32, 1991.

[11] J. Benitez-Malvido, "Impact of forest fragmentation on seedling abundance in a tropical rain forest," Conservation Biology, vol. 12, no. 2, pp. 380-389, 1998.

[12] M. A. Oliveira, A. S. Grillo, and M. Tabarelli, "Forest edge in the Brazilian Atlantic forest: drastic changes in tree species assemblages," Oryx, vol. 38, no. 4, pp. 389-394, 2004.

[13] I. M. Turner, "Species loss in fragments of tropical rain forest: a review of the evidence," Journal of Applied Ecology, vol. 33, no. 2, pp. 200-209, 1996.

[14] P. A. Zuidema, J. A. Sayer, and W. Dikman, "Forest fragmentation and biodiversity: the case for intermediated-sized conservation areas," Environmental Conservation, vol. 23, pp. 290-297, 1996.
[15] M. Tabarelli, J. M. Cardoso Da Silva, and C. Gascon, "Forest fragmentation, synergisms and the impoverishment of neotropical forests," Biodiversity and Conservation, vol. 13, no. 7, pp. $1419-1425,2004$.

[16] R. C. G. Mesquita, P. Delamônica, and W. F. Laurance, "Effect of surrounding vegetation on edge-related tree mortality in Amazonian forest fragments," Biological Conservation, vol. 91, no. 2-3, pp. 129-134, 1999.

[17] R. K. Didham and J. H. Lawton, "Edge structure determines the magnitude of changes in microclimate and vegetation structure in tropical forest fragments," Biotropica, vol. 31, no. 1, pp. 17-30, 1999.

[18] M. Oosterhoorn and M. Kappelle, "Vegetation structure and composition along an interior-edge-exterior gradient in a Costa Rican montane cloud forest," Forest Ecology and Management, vol. 126, no. 3, pp. 291-307, 2000.

[19] J. C. Jiquan Chen, J. F. Franklin, and T. A. Spies, "Vegetation responses to edge environments in old-growth Douglas-fir forests," Ecological Applications, vol. 2, no. 4, pp. 387-396, 1992.

[20] B. J. Fox, J. E. Taylor, M. D. Fox, and C. Williams, "Vegetation changes across edges of rainforest remnants," Biological Conservation, vol. 82, no. 1, pp. 1-13, 1997.

[21] R. P. C. Temu and S. M. Andrew, "Endemism of plants in the Uluguru Mountains, Morogoro, Tanzania," Forest Ecology and Management, vol. 255, no. 7, pp. 2858-2869, 2008.

[22] D. S. Kacholi, Effects of habitat fragmentation on biodiversity of Uluguru Mountain forests in Morogoro region, Tanzania [Ph.D. thesis], Georg-August University Goettingen, Goettingen, Germany, 2013.

[23] W. D. Newmark, "Tanzanian forest edge microclimatic gradients: dynamic patterns," Biotropica, vol. 33, no. 1, pp. 2-11, 2001.

[24] R. M. Seaby and P. A. Henderson, Species Diversity and Richness Version 4, Pisces Conservation Ltd, Lymington, UK, 2006.

[25] A. N. Magurran, Measuring Biological Diverisy, Blackwell Science Ltd. A Blackwell Publishing Company, Melden, Mass, USA, 2004.

[26] N. Myers, R. A. Mittermeier, C. G. Mittermeier, G. A. B. da Fonseca, and J. Kent, "Biodiversity hotspots for conservation priorities," Nature, vol. 403, no. 6772, pp. 853-858, 2000.

[27] S. Madoffe, G. D. Hertel, P. Rodgers, B. O'Connell, and R. Killenga, "Monitoring the health of selected eastern arc forests in Tanzania," African Journal of Ecology, vol. 44, no. 2, pp. 171$177,2006$.

[28] N. D. Burgess and G. P. Clarke, The Coastal Forests of Eastern Africa, IUCN, Cambridge, UK, 2000.

[29] J. P. Mrema, Conservation of Brachylaena huillensis O. Hoffm (Asteraceae) in Dindili Forest Reserve Morogoro [M.S. thesis], Addis Ababa University, 2006.

[30] S. P. Rwamugira, Impact of mining on forest ecosystem and adjacent communities of Eastern Arc Mountains. A case study of Ruvu catchment forest reserve [M.S. dissertation], Sokoine University of Agriculture, 2008.

[31] N. D. Burgess and C. Muir, "Coastal forests of Eastern Africa: biodiversity and conservation," in Proceedings of the Workshop held at the University of Dare s Salaam, Society for Environmental Exploration/Royal Society for the Protection of Birds, UK, 1994.

[32] G. Eilu, D. L. N. Hafashimana, and J. M. Kasenene, "Density and species diversity of trees in four tropical forests of the Albertine rift, western Uganda," Diversity and Distributions, vol. 10, no. 4, pp. 303-312, 2004 
[33] F. Wittmann, J. Schöngart, J. C. Montero et al., “Tree species composition and diversity gradients in white-water forests across the Amazon Basin," Journal of Biogeography, vol. 33, no. 8, pp. 1334-1347, 2006.

[34] A. Gentry, "Changes in plant community diversity and floristic composition on environmental and geographical gradients," Annals of Missouri Botanical Garden, vol. 75, pp. 1-34, 1988.

[35] M. W. Cadotte, R. Franck, L. Reza, and J. Lovett-Doust, “Tree and shrub diversity and abundance in fragmented littoral forest of southeastern Madagascar," Biodiversity and Conservation, vol. 11, no. 8, pp. 1417-1436, 2002.

[36] P. Addo-Fordjour, S. Obeng, A. K. Anning, and M. G. Addo, "Floristic composition, structure and natural regeneration in a moist-semi deciduous forest following anthropogenic disturbances and plant invasion," International Journal of Biodiversity and Conservation, vol. 1, no. 2, pp. 21-37, 2009.

[37] E. N. Mwavu, Human impact, plant communities, diversity and regeneration in Budongo forest reserve, North-Western Uganda [Ph.D. thesis], University of the Witwatersrand, Johannesburg, 2007.

[38] M. Kent and P. Coker, Vegetation Description and Analysis, Belhaven Press, London, UK, 1992.

[39] S. B. Fontoura, G. Ganade, and J. Larocca, "Changes in plant community diversity and composition across an edge between Araucaria forest and pasture in South Brazil," Revista Brasileira de Botanica, vol. 29, no. 1, pp. 79-91, 2006.

[40] G. Williams-Linera, "Vegetation structure and environmental conditions of forest edges in Panama," Journal of Ecology, vol. 78, no. 2, pp. 356-373, 1990.

[41] G. R. Matlack, "Vegetation dynamics of the forest edge-trends in space and successional time," Journal of Ecology, vol. 82, no. 1, pp. 113-123, 1994.

[42] S. M. Gehlhausen, M. W. Schwartz, and C. K. Augspurger, "Vegetation and microclimatic edge effects in two mixedmesophytic forest fragments," Plant Ecology, vol. 147, no. 1, pp. 21-35, 2000.

[43] O. Honnay, K. Verheyen, and M. Hermy, "Permeability of ancient forest edges for weedy plant species invasion," Forest Ecology and Management, vol. 161, no. 1-3, pp. 109-122, 2002.

[44] V. Kapos, "Effects of isolation on the water status of forest patches in the Brazilian Amazon," Journal of Tropical Ecology, vol. 5, no. 2, pp. 173-185, 1989.

[45] L. V. Ferreira and W. F. Laurance, "Effects of forest fragmentation on mortality and damage of selected trees in Central Amazonia," Conservation Biology, vol. 11, no. 3, pp. 797-801, 1997.

[46] W. F. Laurance, "Fragmentation and plant communities: synthesis and implications for landscape management," in Lessons from Amazonia: The Ecology and Conservation of a Fragmented Forest, Yale University Press, New Haven, Conn, USA, 2001.

[47] M. A. Cochrane and W. F. Laurance, "Fire as a large-scale edge effect in Amazonian forests," Journal of Tropical Ecology, vol. 18, no. 3, pp. 311-325, 2002.

[48] M. Yan, Z. Zhong, and J. Liu, "Habitat fragmentation impacts on biodiversity of evergreen broadleaved forests in Jinyun Mountains, China," Frontiers of Biology in China, vol. 2, no. 1, pp. 62-68, 2007.

[49] S. Jose, A. R. Gillespie, S. J. George, and B. M. Kumar, "Vegetation responses along edge-to-interior gradients in a high altitude tropical forest in peninsular India," Forest Ecology and Management, vol. 87, no. 1-3, pp. 51-62, 1996. 

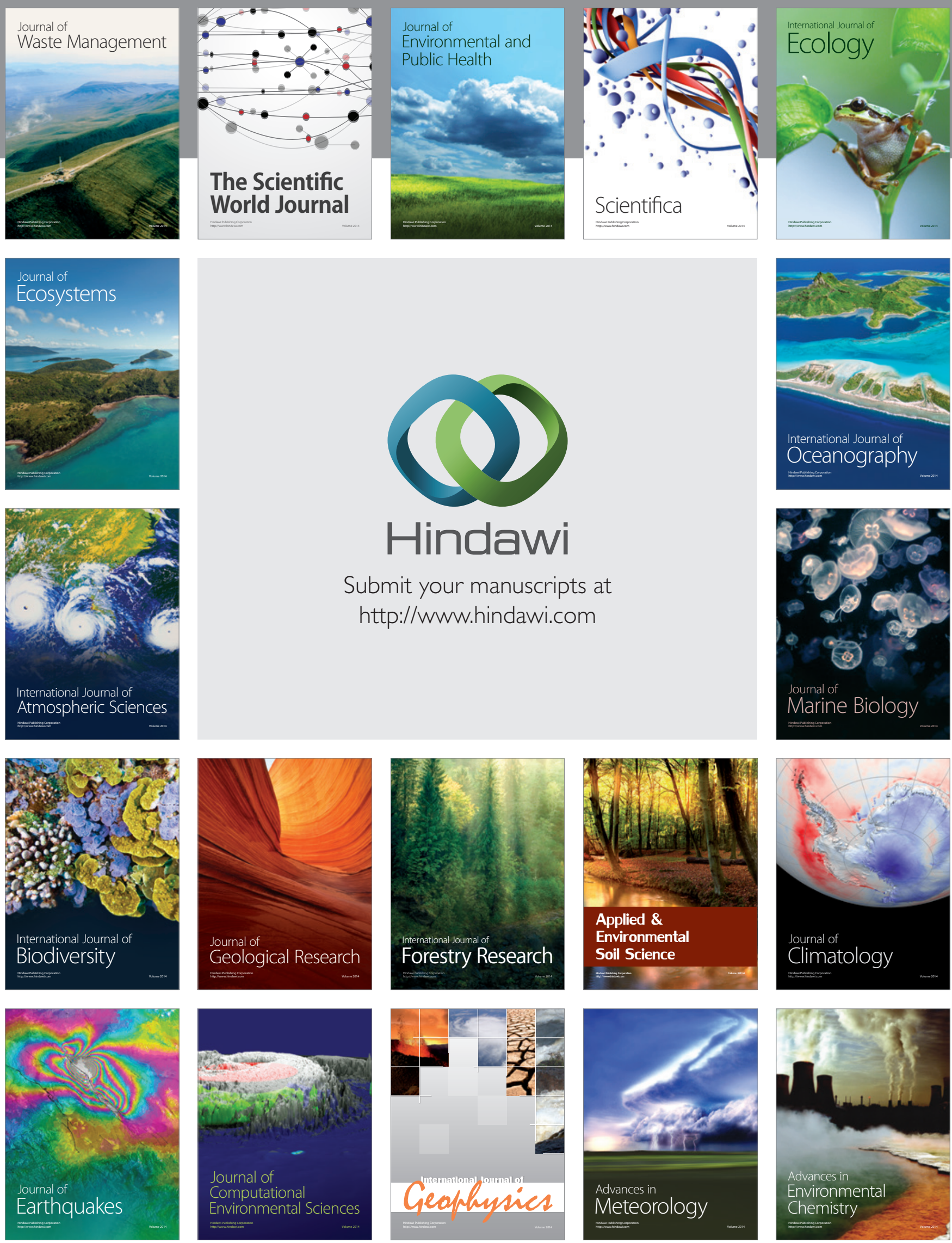